\title{
Anatomi Kejahatan Korporasi dan Penanggulangannya
}

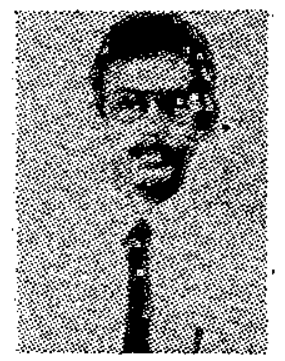

Salman Luthan

Pendahuluan

Kejahatan Korprasi kini telah menjadi citrà global dunia modern. Indentifikasi dain penanganannya yang cukup sulit kian memperjelas bahwa ia merupakan problem hukum yang dilematis. Banyak faktor yang mendorong terciptanya kejahatan ini, dan menurut Salman Luthan, penegakan hukum yang konsisten saja, belumlah cukup untuk menanggulanginya. Karena memang untuk menanggulanginya diperlukan

\section{Pendahuluan}

KORPORASI adalah term yang lazim digunakan dalam hukum pidana untuk menyebut badan hukum (rechtspersoon atau legal entity) yang sudah melembaga dalam bidang hukum perdata ${ }^{1)}$. Korporasi ini merupakan badan hasil ciptaan hukum yang unsur-unsurnya terdiri dari corpus (struktur fisiknya) dan animus (kepribadiannya). Oleh karena badan itu merupakan ciptaan hukum, maka kematiannya pun ditentukan oleh hukum ${ }^{2}$.

Penciptaan korporasi adalah untuk menjawab tuntutan perkembangan ekonomi dan bisnis pada zaman revolusi industri yang semakin luas dan kompleks, terutama masalah keterbatasan dana untuk pembiayaan industriindustri besar dan masalah pengorganisasian kerja-sama antara para pemilik modal dalam melaksanakan aktivitas ekonomi dan bisnis. Proyek-proyek besar membutuhkan dana yang sangat banyak, sementara jumlah modal perorangan terbatas. Agar proyek tersebut dapat dikerjakan, maka modal perorangan itu perlu digabungkan, dan dengan penggabungan modal itu perlu pula diatur pengorganisasian kerja samanya.

Korporasi ialah suatu gabungan orang yang dalam pergaulan hukum, bertindak bersamasama sebagai suatu subyek hukum tersendiri, suatu personifikasi. Korporasi adalah badan hukum yang beranggota, tetapi mempunyai hak dan kewajiban sendiri terpisah dari hak kewajiban anggota masing-masing ${ }^{3)}$.

Sebagai subyek hukum, korporasi adalah pendukung hak dan kewajiban sebagaimana halnya subyek hukum orang (natuurlijke persoon). Dengan demikian korporasi dapat me- 
lakukan perbuatan-perbuatan hukum, seperti melakukan transaksi bisnis, mengadakan perjanjian kredit, hak untuk memiliki barang dan harta kekayaan, hak untuk menuntut dan dituntut. Namun ada beberapa jenis tindakan hukum yang tidak dapat dilakukan korporasi, seperti perkawinan dan pewarisan.

Pada zaman era informasi sekarang perkembangan korporasi telah mencapai tingkat yang sangat mengagumkan. Hampir tidak ada bidang kehidupan kita yang terlepas dari jaringan korporasi, baik korporasi nasional maupun korporasi multinasional (transnasio nal). Apalagi dengan adanya globalisasi ekonomi dunia, yang mengakibatkan makin tingginya ketergantungan antara negara yang satu dengan negara lainnya.

Sesungguhnya setiap perkembangan pokok pada abad ini berasal dari organisasi (korporasi). Biotek engeneering, computer, apollo, mobil, dan sebagainya berasal dari organisasi. Organisasi mempunyai peranan sentral dalam kehidupan kita. Air yang kita minum, makanan yang kita makan, pakaian yang kita pakai, dan kendaraan-kendaraan yang kita pakai atau transportasi umum yang kita gunakan berasal dari organisasi ${ }^{4}$.

Organisasi adalah aransemen sosial yang paling berdaya cipta pada abad kita ini dan peradaban. Adalah suatu kemukjizatan untuk mengetahui bahwa puluhan dari beribu-ribu orang dengan latar-belakang pribadi, ketrampilan, dan kepentingan-kepentingan yang tinggi dikoordinasi dalam korporasi-korporasi untuk mengejar tujuan-tujuan umum yang direncana$\operatorname{kan} 5$.

Peranan korporasi dalam tata kehidupan manusia semakin meningkat dari waktu ke waktu, sejalan dengan perkembangan korporasi, khususnya dalam tingkat perekonomian dunia. Pada awalnya korporasi hanya beroperasi dalam lingkup wilayah yang terbatas dengan unit usaha yang terbatas pula. Sejalan dengan perkembangan ekonomi dunia, korporasi berkembang menjadi perusahaan-perusahaan raksasa, yang unit usahanya menjangkau begitu banyak bidang kehidupan, dan beroperasi dalam lintas negara.
Kalau kita memperhatikan unit-unit di dunia, pada umumnya kita berpikir dalam rangka bangsa-bangsa, yang jumlahnya kini lebih dari 150 negara. Namun lebih dari 40 unit ekonomi terbesar di dunia adalah perusahaan-perusahaan multinasional, bukan negara. Ini memberi satu gambaran kepada kita, bagaimana pentingnya keterlibatan mereka dalam pembangunan ${ }^{6)}$.

Kehadiran perusahaan-perusahaan multinasional dalam pembangunan di Dunia Ketiga telah menimbulkan sikap ambivalen. Pada satu sisi ada yang menentang kehadiran perusahaan-perusahaan tersebut, karena dianggap hanya ingin mengeruk kekayaan alam negaranegara berkembang dan menciptakan ketergantungan kepada negara-negara maju. Tapi pada sisi yang lain ada yang berpandangan bahwa perusahaan-perusahaan multinasional tersebut justru mendatangkan keuntungan bagi Dunia Ketiga, karena tersedianya modal dan terjadinya proses alih teknologi.

Hal-hal yang dapat dilakukan perusahaan multinasional dalam pembangunan adalah: Pertama, dorongan untuk memperoleh keuntungan, sebab tanpa keuntungan perusahaan tidak dapat hidup. Kedua, perusahaan multinasional dapat menyumbang sesuatu yang tidak dapat dilakukan sebagian besar pemerintah Dunia Ketiga dan perusahaan-perusahaan setempat (lokal), yakni modal. Ketiga, perusahaan-perusahaan multinasional menawarkan pengetahuan mereka ke pasaran dunia. Keempat, perusahaan-perusahaan multinasional mempunyai pula kemampuan yang luar biasa untuk mengalihkan ilmu dan teknologi untuk pembangunan. Kelima, masalah penyesuaian teknologi dengan keadaan setempat yang memungkinkan perusahaan-perusahaan multinasional dapat menggalakkan pembangunan, sehingga menjadikan rakyat dapat berswasembada. Keenam, perusahaan-perusahaan multinasional telah memahami saling ketergantungan, mungkin lebih baik dari unit lain di dunia ini ${ }^{7}$.

Untuk menjaga agar prilaku korporasi multinasional, maka Organization of Economic Cooperation and Developtment (OECD) mengeluarkan Deklarasi Tentang Investsi Inter- 
nasional dan Perusahaan Multinasional (21 Juni 1976) sebagai standart prilaku (code of conduct) dalam beroperasi. Namun proses penegakannya bersifat sukarela, tergantung kepada kemauan dari organisasi-organisasi transnasional tersebut ${ }^{8)}$.

Dengan aset yang sangat besar yang dimilikinya, kadang mencapai milyaran dolar, menjadikan korporasi memiliki kekuasaan ekonomi dan politik yang sangat besar. Raksasa- raksasa korporasi ini dapat mengontrol kehidupan ekonomi (dan politik) negara. Misalnya The Campbell Soup Company di AS mengontrol $85 \%$ dari bahan sup, empat perusahaan makanan menyediakan $90 \%$ makanan pagi. Di Indonesia beberapa perusahaan menguasai beberapa manufaktur seperti terigu, otomotif, periklanan, dan sebagainya".

Korporasi besar itu memiliki pengaruh dan oleh karena itu kekuasaan terhadap pemerintah, hal mana tidak dimiliki perusahaan-perusahaan kecil. Dengan berdalih sebagai pembayar pajak terbesar untuk negara, pelbagai jalan ditempuh untuk mempengaruhi para birokrasi dalam kabinet maupun dalam lembaga pemerintah lainnya ${ }^{10)}$.

Kekuasaan besar yang dimiliki oleh korporasi, baik korporasi domestik, apalagi korporasi multinasional, bukan hanya dapat diandalkan dalam pembangunan ekonomi untuk meningkatkan kesejahteraan hidup masyarakat. Tetapi juga mengandung potensi yang sangat besar untuk melakukan kejahatan korporasi, yang dapat merugikan negara, masyarakat, lingkungan, maupun sistem keselamatan anggota badan.

\section{Arti dan Ruang Lingkup Kejahatan Korporasi}

KETIKA membahas kejahatan korporasi para pakar umumnya merujuk kepada Sutherland, karena dialah yang pertama kali mengintrodusir white collar crime yang dipresentasikannya pada pertemuan tahunan American Sociological Society yang ke-34 pada tahun 1939. Terminologi white collar crime itu digunakannya untuk menjelaskan prilaku korporasi-korporasi Amerika Serikat yang melanggar hukum dan merugikan masyarakat luas.
Namun menurut Van den Heuvel, tiga puluh tahun sebelumnya, 1907, E.A. Ross telah mengupas masalah tersebut lebih dahulu beserta pemecahannya. Dalam bukunya Sin and Society, dia memperhatikan semua pelanggaran hukum yang dilakukan korporasi dan administrasi, yang dianggap tidak hanya sebagai kejahatan tetapi juga sebagai dosa modern (modem $\sin )^{11)}$.

Sutherland mendefinisikan white collar crime sebagai suatu pelanggaran ketentuan hukum pidana oleh orang (persoon) yang mempunyai kedudukan sosio-ekonomi atas dalam bidang aktivitas pekerjaannya ${ }^{12)}$ sealur dengan pemikiran Sutherland; Edelhertz mendefinisikan white collar crime sebagai tindakan illegal atau serangkaian tindakan illegal yang dilakukan dengan cara nonfisik dan dengan penyembunyian atau tipu-musihat untuk memperoleh uang atau harta benda dan untuk memperoleh pemanfaatan peroangan ${ }^{13)}$.

Agak bertolak belakang dengan Sutherland dan Edelhertz yang menempatkan pelanggaran ketentuan hukum pidana sebagai karakteristik normatif dari white collar crime, E.A. Ross justru meletakkan pelanggaran kaidah moral sebagai ciri kejahatan korporasi. Aspek moral ini jauh lebih penting daripada sisi hukum.

Menurut Ross, kejahatan korporasi tidak diilhami oleh suatu dorongan jahat, tapi oleh hal yang tidak dirasakan moral (moral insesibility). Kata "moral insesibility" itu merupakan kata kunci untuk memahami kejahatan korporasi. Kita menyebutnya kejahatan karena ia sangat melukai perasaan kita tentang keadilan, kejujuran, solidaritas dan tanggung-jawab sosial $^{14)}$

White collar crime terdiri dari dua tipe, yaitu kejahatan okupasi dan kejahatan korporasi. Apabila tindakan melanggar hukum korporasi mengatas-namakan badan hukum, itu merupakan kejahatan korporasi. Namun apabila ia memperoleh keuntungan pribadi dalam menjalankan kejahatan terhadap korporasi, seperti halnya dalam penggelapan dana-dana badan hukum itu, merupakan kejahatan okupasi atau jabatan ${ }^{15)}$. 
Dalam membahas kejahatan korporasi, maka harus dibedakan antara pertama, crimes for corporation, (b) crime against corporation, (c) criminal corporation. Yang pertama di atas sebenarnya yang merupakan kejahatan korporasi. Dalam hal ini dapat dikatakan bahwa corporate crimes are cleraly committed for the corporate. Yang kedua ini sering dinamakan employee crime, sedangkan yang ketiga merupakan korporasi yang sengaja dibentuk dan dikendalikan untuk melakukan kejahatan ${ }^{16)}$.

Kejahatan korporasi juga harus dibedakan dari kejahatan ekonomi pada umumnya, karena kejahatan korporasi hanya dilakukan dalam konteks oleh bisnis besar, bukan yang dilakukan oleh kelompok bisnis kecil. Dengan demikian unsur kejahatan korporasi adalah (a) kejahatan; (b) yang dilakukan oleh orang terpandang/terhormat, (c) dari status sosial tinggi, (d) dalam hubungan dengan peker jaannya, (e) dengan melanggar kepercayaan publik ${ }^{17}$.

Ruang lingkup kejahatan korporasi pada dasarnya meliputi penyalah-gunaan kepercayaan masyarakat (kejahatan korporasi di bidang keuangan, perbankan dan asuransi), kejahatan korporasi terhadap konsumen (penggunaan bahan substitusi yang berbahaya pada produk makanan, minuman dan kosmetika), iklan yang menyesatkan, obat-obatan yang. mempunyai akibat sampingan ${ }^{18)}$.

Pembagian kejahatan korporasi yang lebih komprehensif dikemukakan oleh Joseph $F$. Sheley. Dia membagi kejahatan korporasi dalam 6 katagori, yaitu: (a) menggelapkan/menipu para pemegang saham (misalnya tidak melaporkan dengan sebenarnya keuntungan perusahaan), (b) menipu publik/ masyarakat (misalnya penentuan harga dan produk-produk yang tidak representatif, (c) menipu pemerintah (misalnya menghindari pajak), (d) membahayakan kesejahteraan umum (misalnya menimbulkan polusi industri), (e) membahayakan pekerja (misalnya tidak mempedulikan keselamatan kerja), dan (f) intervensi illegal dalam proses politik (misalnya memberikan dana kampanye politik yang illegal) ${ }^{19}$ ).

Dalam sistem hukum Indonesia, jenis keja- hatan korporasi menurut D. Soedjono meliputi: kejahatan korporasi di bidang ideologi politik (UU No. 11/PNPS/1963 tentang Tindak Pidana Subversi), kejahatan korporasi di bidang ekonomi (UU No. 7 Drt. 1955 tentang Tindak Pidana Ekonomi), penyelundupan, uang palsu, penyimpangan pajak, korupsi; kejahatan korporasi dalam bidang sosial budaya, delik hak cipta, pencurian barang-barang purbakala, narkotika, suap; kejahatan korporasi di bidang pertahanan dan keamanan, yaitu UU No. 8/1994 tentang Tindak Pidana Imigrasi, berhubungan dengan pemalsuan paspor, imigran gelap, dan sebagainya.

Di samping itu, termasuk pula dalam ruang lingkup kejahatan korporasi adalah pencemaran lingkungan, ancaman kesehatan dan keselamatan kerja para tenaga kerja, produk makanan yang tidak aman, biskuit beracun, obatobatan, iklan yang menyesatkan, penipuan dengan menyalahgunakan komputer, penyimpangan di bidang perbankan, pemalsuan suratsurat, membohongi rakyat (Yayasan Kesejahteraan Adil Makmur), penipuan tenaga ker ja ${ }^{20)}$.

Klasifikasi kejahatan korporasi yang dikemukakan oleh Soedjono ini agak rancu, karena tidak jelasnya kriteria penyusunan klasifikasi tersebut. Setiap jenis kejahatan yang mungkin dilakukan oleh korporasi dikualifisirnya sebagai kejahatan korporasi. Padahal kejahatan korporasi memiliki karakteristik khusus, misalnya kejahatan itu berkaitan dengan kegiatan ekonomi atau berhubungan dengan dunia bisnis besar, dan pelakunya adalah dari kelompok masyarakat berstatus sosial ekonomi terpandang.

Dengan adanya kejahatan korporasi, anggapan bahwa kejahatan hanya dilakukan oleh rakyat atau orang-orang lapisan bawah, sedikit banyak merupakan suatu mitos atau ilusi belaka ${ }^{21)}$. Kuantitas kejahatan jalanan yang dilakukan oleh kelompok masyarakat lapisan bawah memang lebih banyak, tapi kerugian yang ditimbulkan oleh kejahatan korporasi jauh lebih besar daripada kerugian yang diakibatkan kejahatan jalanan. 


\section{Fenomena Kejahatan Korporasi}

DALAM kepustakaan hukum pidana dan kriminologi banyak dikemukakan kasus-kasus kejahatan korporasi yang terjadi di berbagai negara dari belahan bumi ini. Kasus-kasus itu terdiri dari pelbagai jenis kejahatan korporasi, misalnya produk makanan atau obat-obatan yang tidak memenuhi syarat kesehatan, penye- lewengan keuangan, kecelakaan kerja, kasus penyuapan, dan kasus pencemaran.

Kasus Thalidomide menyebabkan ribuan bayi lahir cacat tanpa tangan, kaki atau anggota tubuh yang lain sebagai akibat dari penggunaan obat Thalidomide oleh ibu-ibu yang sedang mengandung. Kasus ini melanda beberapa negara Eropa dan Amerika Selatan pada tahun 1960-an. Dan kasus ini pada awalnya ingin ditutup-tutupi oleh Pemerintah Inggris dan, baru terbongkar setelah hampir 10 tahun karena jasa anggota parlemen ${ }^{22)}$.

Frank Upham dalam bukunya "Law and Changing Society in Japan" menjelaskan kasus Minamata, yaitu kasus pencemaran yang terjadi di Teluk Minamata, Jepang. Pihak industri dan pemerintah menolak untuk mngakui kerusakan yang besar sekali yang telah diakibatkan oleh industri. Banyak orang mati karena keracunan, banyak yang cacat dan lumpuh, serta lebih banyak lagi yang kehilangan pekerjaan sebagai nelayan $^{23)}$.

Di India pada tahun 1984 terjadi kasus bocornya pabrik kimia Union Carbide di Bhopal, India, pada tahun 1984 telah menewaskan lebih dari tiga ribu orang, ratusan ribu yang sakit dan cacat, bahkan ribuan di antaranya cacat seumur hidup, masih ditambah kerugian materi dan rusaknya lingkungan hidup yang bernilai ratusan juta rupiah. Dalam kasus yang hampir sama, pada tahun 1988 terjadi kebocoran reaktor nuklir Chernobil di Uni Soviet, yang menyebabkan banyak jatuh korban, baik yang meninggal dunia maupun mereka yang terkena radiasi.

Kasus Lockheed Electra, sebuah perusahaan pesawat terbang di AS, sangat menghebohkan dunia karena perusahaan tersebut menyuap pejabat-pejabat tinggi dari beberapa negara, seperti Turki, Belanda, Yunani dan Jepang untuk memperlancar pemasaran pesawat-pesawat produk perusahaan tersebut. Karena kasus Lockheed ini mengakibatkan Tanaka jatuh dari kursi perdana menteri Jepang, dan dicabutnya kekuasaan Pangeran Bernard atas Angkatan Perang Belanda pada pertengahan tahun 70-an.

Senat Amerika Serikat berhasil membongkar kasus penyuapan yang dilakukan korporasi-korporasi negara adidaya itu terhadap berbagai pemerintah asing. Hasil penyelidikan Senat menunjukkan bahwa pada tahun 1945- 1978 hampir 350 korporasi telah mengakui melakukan penyuapan sebesar $\$ 750$ milyar pada para pejabat pemerintah-pemerintah asing ${ }^{24)}$.

Kasus Hooker Chemical, yaitu perusahaan subsider Occidental Petroleum Corporation, mengenai pencemaran lingkungan. Perusahaan tersebut melimbahkan 21.000 ton bahan kimia sedalam 3000 kaki di Love Canal, dekat air terjun Niagara, New York, selama tahun 1942-1953. Tanah tempat pembuangan limbah tersebut kemudian dijual. Karena tak ada pemberitahuan dan peringatan dari perusahaan, maka di sekitar itu dibangun tempat pemukiman rakyat. Pada tahun 1975 penduduk di daerah itu mengeluh karena ada bahan kimia yang timbul di permukaan. Dalam gugatan sebẹsar $\$ 635$ milyar terhadap Occidental dan anak perusahaannya Hooker, Negara Bagian New York menuduh bahwa bahan kimia limbahan yang dibuang di tempat itu mengandung bahan yang diduga menyebabkan penyakit kanker, kerusakan kelahiran bayi atau bayi cacat, perubahan genetika, dan kondisi merugikan yang akut dan kronis terhadap tubuh manusia, dan yang merusak dan diduga merusak tanaman dan kehidupan hewan ${ }^{25}$ ).

Di Amerika Serikat dan di negara-negara Eropa Barat banyak terjadi kasus-kasus kecelakaan kerja mendatangkan kerugian kepada para pekerja, baik cacat fisik maupun meninggal dunia, dan gugatan konsumen terhadap perusahaan. Misalnya, Ford Motor Company oleh negara bagian Indiana pada tahun 1978 dituduh melakukan pembunuhan alpa karena 
diyakini ia sengaja mengizinkan mobil Pinto yang tidak aman untuk dijual.

Banyak perusahaan multinasional Barat bekerja dengan bahan-bahan dari Dunia Ketiga, yang dilarang di negaranya sendiri. Misalnya, bedak susu (milk powder) dilarang untuk dikonsumsi di Eropa, tetapi perusahaan multinasional mengalihkan penjualannya ke Afrika. Jadi perusahaan multinasional menjadi moralis di negaranya dan menjadi kriminal di luar negeri ${ }^{26)}$.

Kerugian yang diakibatkan oleh kejahatan korporasi ini bagi individu, masyarakat dan negara adalah sangat besar. Apa yang terlihat hanyalah "puncak gunung es" saja. Persekongkolan dalam penentuan harga (fixing prices) bahan makanan pokok atau mengiklankan secara menyesatkan barang keperluan rumah tangga akan menimbulkan kerugian uang yang sangat besar pada penghasilan warga masyarakat. Barang produksi yang tidak aman dipergunakan dapat menimbulkan kerugian badan kepada para pemakainya. Pencemaran lingkungan dan kerusakan lingkungan menimbulkan kerugian yang tidak saja dialami sekarang, tetapi masih pula akan dirasakan di kemudian hari ${ }^{27)}$.

Kasus-kasus kejahatan korporasi yang banyak terjadi di Indonesia adalah kasus pencemaran lingkungan, kasus manipulasi restitusi pajak, produk makanan yang membahayakan seperti kasus biskuit beracun, korupsi; iklan yang menyesatkan, manipulasi dana masyarakat seperti kasus Bank Summa dan Golden Key Group, dan kasus- kasus kecelakaan kerja.

\section{Faktor-faktor Kriminogen}

VARIABEL-variabel sosiologis yang mendorong atau menyebabkan korporasi melakukan tindakan melawan hukum, terutama menyangkut kejahatan korporasi, bukan disebabkan oleh variabel tunggal, melainkan oleh berbagai variabel. Dengan kata lain, banyak faktor yang mempengaruhi perusahaan dalam melakukan kejahatan korporasi.

Menurut Clinard dan Yeager ada dua pandangan yang dapat dipakai untuk menjelaskan kejahatan bisnis, yaitu model tujuan yang rasional, yakni yang mengutamakan untuk mencari keuntungan, dan model organik, yang menekankan pada hubungan antara perusahaan dengan lingkungan ekonomi dan politiknya, yaitu supplier, pesaing, konsumen, pemerintah, publik, serta kelompok-kelompok lainnya yang dipandang relevan.

Motivasi untuk mencari keuntungan yang sebesar-besarnya merupakan faktor tunggal yang paling memaksa, atau mengharuskan di belakang adanya penyimpangan-penyimpangan oleh industri besar, apakah itu mengenai pengaturan atau penetapan atau pemasangan harga-harga, menghancurkan persaingan atau produk-produk yang keliru ${ }^{28)}$.

Steven Box memperinci faktor-faktor organik yang secara potensial mengganggu kemampuan korporasi dalam mencapai tujuannya, sehingga dapat menghasilkan tekanan untuk melakukan kejahatan, yaitu (a) persaingan (memata-matai industri, persaingan illegal, price fixing hingga pembakaran-pembakaran), (b) pemerintah (dana-dana kampanye politik yang illegal, pemberian informasi yang salah terhadap laporan rutin), (c) karyawan (peralatan $\mathrm{kerja/mesin-mesin} \mathrm{yang} \mathrm{tidak} \mathrm{aman,} \mathrm{gangguan}$ illegal dari perserikatan, termasuk penggunaan dari sindikat-sindikat kejahatan, (d) konsumen (iklan yang menyesatkan, pemberian label yang dipalsukan, menjual barang-barang kadaluarsa, produk-produk yang membahayakan, tanpa pengujian atau memanipulasi hasil pengujian), (e) masyarakat (polusi, menjarah sumber-sumber yang bersifat nasional, penghindaran pajak, penyuapan dan korupsi untuk merusak proses demokrasi) $^{29)}$.

Di samping variabel motivasi untuk mendapat keuntungan yang sebesar-besarnya yang tercermin dari ciri-ciri individual yang disebut sebagai anomie of success, dan hubungan (kontradiksi) antara korporasi dengan lingkungan ekonomi dan politiknya. Muladi menambahkan sistem penegakan hukum yang tidak efektif sebagai motivasi pèrusahaan untuk melakukan kejahatan korporasi. Penegakan hukum pidana yang tidak efektif itu tergambar dari penjatuhan pidana yang sangat ringan, kurangnya kriminalisasi dan stigmatisasi, daya tangkal, kurangnya reaksi sosial melalui mass media serta 
kesempatan yang luas juga sangat mendorong proses transformasi di atas ${ }^{30)}$.

Sieber (1979) dalam penelitiannya telah mengemukakan bahwa struktur badan hukum transnasional suatu negara memberi fasilitas untuk melanggar hukum yang berbentuk tindakan penghindaran undang-undang nasional, dengan manipulasi harga-harga agar dapat membayar pajak lebih murah. Kesulitan-kesulitan menyelidiki illegalitas transnasional di luar negeri bagi negara-negara yang terkena, dan masalah pertanggung-jawaban badan hukum induk bagi perbuatan dan tindakan cabang-cabang di luar negeri, juga cenderung mendorong perbuatanperbuatan kejahatan oleh badan-badan hukum transnasional di mana saja ${ }^{31)}$.

Kekuatan negara dan kekuatan industri yang menyatu dapat mengarah kepada situasi kekuasaan yang tak terkendali sehingga hampir selalu bersifat kriminogen, khususnya untuk kejahatan white collar dan korupsi. Dengan kata lain, faktor kekuasaan yang seperti itu dapat. menggugah untuk melakukan kejahatan. Dalam konteks seperti itu adalah sangat sukar bagi rakyat untuk mengajukan satu kasus dan bagi hakim yang independen untuk mempercayai bahwa kekuasaan itu adalah salah ${ }^{32)}$.

\section{Upaya Penanggulangan}

PENEGAKAN hukum yang konsisten merupakan sarana yang paling efektif untuk mengendalikan kecenderungan makin meningkatkan kejahatan korporasi, tetapi ternyata banyak hambatan yang muncul dalam proses penegakan hukum. Faktor-faktor yang menjadi hambatan itu terdapat dalam sistem hukum itu sendiri, maupun faktor-faktor di luar sistem hukum.

Kesulitan dalam penegakan hukum ataupun pengendalian kejahatan korporasi terletak dalam dua hal. Pertama, korporasi (sebagai pelaku kejahatan yang potensial) pada umumnya mempunyai lobby yang efektif dalam usaha perumusan delik maupun cara-cara menanggulangi kejahatan korporasi. Kedua, menentukan pertanggung-jawaban pidana korporasi maupun menentukan kesalahan korporasi tidaklah mudah ${ }^{33)}$.
Untuk kasus Indonesia, adanya kesulitan dalam menuntut pertanggung-jawaban pidana korporasi terutama disebabkan oleh kelemahan dalam peraturan perundang-undangan. Walaupun hukum pidana kita telah mengakui korporasi sebagai subyek tindak pidana korporasi, namun hukum pidana kita bersifat mendua dalam masalah pertanggung-jawaban pidana korporasi ini. Artinya, ketentuan umum dalam KUHP tidak mengakui pertangging-jawaban pidana korporasi, sebaliknya dalam undangundang tertentu korporasi dapat dipertanggung-jawabkan secara pidana, misalnya dalam tindak pidana ekonomi (UU No. 7 Drt/1955).

Vold dalam "Theoritical Criminology" (1958) yang dikutip Sahetapy dalam bukunya Kejahatan Korporasi, mengenai white collar crime mengemukakan bahwa tidak ada official atau definisi hukum mengenai white collar crime. Konsep kejahatan white collar di mana pun adalah tetap ambigu, tidak pasti dan kontroversial.

Dari proses peradilan kasus Minimata di Jepang, kita dapat mengetahui bahwa kekuasaan negara yang menyatu dengan kekuasaan industri bukan hanya menjadi faktor kriminogen terhadap kejahatan korporasi, tetapi kondisi tersebut merupakan penghambat utama dalam penegakan hukum.

Hakim-hakim bawahan yang memeriksa kasus itu takut untuk menyalahkan industri. Mereka menolak untuk menerima bukti-bukti yang diberikan petugas kesehatan medis, dan kemudian oleh menteri kesehatan masyarakat. Studi Upham memperlihatkan bahwa kejahatan korporasi adalah kejahatan yang bersifat tipikal, suatu kejahatan tentang ketiadaan kontrol atas kekuasaan (a crime of uncontrolled overpower) ${ }^{34)}$.

Mengapa kasus-kasus kejahatan korporasi yang terjadi di tanah-air kita jarang yang diajukan ke pengadilan? Karena penegakan hukum pidana terhadap pelaku kejahatan korporasi adalah sulit, karena banyak kejahatan yang belum dirumuskan sebagai kejahatan. $\mathrm{Di}$ samping itu proses pembuktian terhadap kejahatan korporasi bukan hal yang gampang. Ditambah lagi dengan pers yang hanya diisi de- 
ngan "hari-hari omong kosong" ${ }^{35)}$.

Menurut Van den Heuvel ada lima faktor yang menjadi hambatan dalam pengendalian kejahatan korporasi, yaitu faktor undang-undang, mekanisme penyelidikan yang tidak dapat dipercaya dan tidak adekuat (karena keter- batasan kemampuan dan kemampuan personal), kompleksitas pembuktian, masalah hakim dan kehakiman (kejahatan korporasi membutuhkan kompetensi untuk menginterpretasikan secara khusus sehingga dapat membedakan antara kejahatan korporasi dengan kejahatan lainnya, dan menentukan jenis hukuman dan siapa yang harus dihukum.

Untuk menanggulangi kejahatan korporasi dengan segala dampak negatif yang ditimbulkannya, maka tanpa mengurangi peranan hukum pidana sebagai ultimum remedium, agaknya perlu dipertimbangkan peranan hukum pidana sebagai primum remedium terhadap kejahatan korporasi. Hal ini tentunya dengan melihat ciri-cirinya yang melekat pada korporasi serta perkembangannya di masa-masa mendatang ${ }^{36}$ ).

Kelemahan dalam peraturan perundang-undangan sebenarnya dapat diatasi dengan menerapkan asas identifikasi, yaitu asas yang menyamakan tindakan korporasi dengan tindakan orang secara pribadi. Misalnya suatu perusahaan dituduh telah melakukan delik common law, ialah bermufakat untuk menggelapkan atau menipu (conspiracy to fraud), suatu delik yang mensyaratkan adanya mens rea dan tidak dimungkinkan adanya vicarious liability. Dalam hal ini pengadilan memandang atau menganggap bahwa perbuatan dan sikap batin dari pejabat tertentu yang dipandang sebagai perwujudan dari kedirian organisasi tersebut adalah perbuatan dan sikap batin korporasi ${ }^{37}$ )

Dalam hal ini korporasi bukannya dipandang bertanggung jawab atas dasar pertanggung-jawaban dari perbuatan pejabatnya, melainkan korporasi itu seperti halnya dalạm pelanggaran terhadap kewajiban hukum justru dipandang telah melakukan delik itu secara pribadi. Namun sayangnya asas ini juga tidak dikenal dalam hukum pidana kita.
Menurut Van Den Heuvel ada empat sarana untuk menanggulangi kejahatan korporasi, yaitu: pertama, struktur kekuasaan negara merupakan salab satu alat untuk memerangi kejahatan korporasi dan korupsi. (Peranan parlemen untuk melakukan investigasi terhadap pejabat administrasi. Pembagian kekuasaan antara eksekutif dan legislatif serta yudikatif merupakan senjata yang ampuh). Kedua, kondisi publik yang mendukung, yaitu media yang independen dan publisitas. Ketiga, peradilan khusus (special court), dan aksi rakyat, misalnya di Amerika Serikat ada lembaga The Interfaith Centre on Corporation Responsibility (Pusat Antar Agama bagi Tanggung Jawab Korporasi).

Bagi negara kita upaya penanggulangan kejahatan korporasi perlama-tama harus dimulai dengan pembaruan aturan perundang-undangan, khususnya kedudukan korporasi sebagai pelaku tindak pidana dan pertanggungjawaban pidana korporasi. Dalam RUU KUHP Nasional masalah ini telah dirumuskan. Ide peradilan khusus bagi kejahatan korporasi adalah cukup tepat, karena kejahatan bersifat kompleks, dan karena itu dibutuhkan pengetahuan yang mendalam dan ketrampilan yang prima untuk memahami dan menegakkannya.

Kemudian faktor yang tidak kalah pentingnya adalah penumbuhan kesadaran rakyat untuk melawan tindakan-tindakan korporasi yang sangat merugikan negara, masyarakat, dan konsumen. Dan yang upaya lainnya adalah menegakkan independensi pengadilan sebagai benteng terakhir untuk memperjuangkan keadilan.

Salman Luthan, SH, adalah staf pengajar FH UII dan juga alumnus fakultas yang sama. Aktif menulis di berbagai media. Saat ini sedang menyelesaikan jenjang S-2 di Universitas Indonesia.

\section{Catatan Kaki:}

1) Rudi Prasetyo, Perkembangan Korporasi dalam Proses Modemisasi dan Penyimpangan-penyimpangannya, makalah disampaikan pada Seminar Nasional Kejahatan Korporasi, FH UNDIP, 23-24 November 1989, hal. 2. 
2) Satjipto Rahardjo, Ilmu Hukum, Bandung: Alumni, 1987, hal. 110.

3) Chaidir Ali mengutip Utrecht dan Moh. Saleh Djindang dalam Badan Hukum, Bandung: Alumni, 1987, hal. 64.

4) William B. Wither, Jr dan Keit Davis, Human Resources and Personnel Management, New York: McGraw-Hill, INC., 1993, hal: 6.

5) Ibid.

6) Pieter Kuin (penyunt.), Perusahaan Trans Nasional, Jakarta: Yayasan Obor Indonesia dan PT. Gramedia, 1987, hal. 26.

7) Ibid., hal. 25-29.

8) Ibid.

9) IS. Susanto, Kejahatan Korporasi, makalah disampaikan pada Penataran Nasional Hukum Pidana dan Kriminologi untuk dosen-dosen PTN/PTS se-Indonesia, FH UNDIP, 12-31 Januari 1993.

10) J.E. Sahetapy, Kejahatan Korporasi, Bandung: Eresco, 1994, hal. 7-8.

11) G.A.A.J. Van Den Heuvel, Corporite Crime, makalah disampaikan pada Seminar Nasional Kejahatan Korporasi, FH UNDIP, 23-24 November 1989, hal. 3.

12) B. Mardjono Reksodiputro, Pertanggung-jawaban Pidana Korporasi dalam Kejahatan Korporasi, makalah pada Seminar Kejahatan Korporasi, FH UNDIP, 23-24 November 1989.

13) D. Soedjono, Anatomi Kejahatan Korporasi di Indonesia, makalah pada seminar nasional Kejahatan Korporasi, FH UNDIP, 23- 24 November 1989, hl. 7.

14) Hevel, Op. Cit., hal. 4.

15) Soedjono, Op. Cit., hal. 7.

16) Muladi dan Dwija P., Pertanggung-jawaban Korporasi dalam Hukum Pidana, Bandung: Alumni, 1991, hal. 175.

17) Mardjono Reksodiputro, Op. Cit., hal. 3.

18) Susanto, Op. Cit., hal. 4.

19) Joseph F. Sheley, Exploring Ciime, 1987, hal. 108.

20) D. Soedjono, Op. Cit., hal. 12-23.

21) J.E. Sahetapy, Op. Cit., hal. 9.

22) I.S. Susanto, Op. Cit., hal. 9.

23) Heuvel, Op. Cit., hal.

24) J.E. Sahetapy, Op. Cit, hal. 6.

25) D. Soedjono, Op. Cit., hal. 12.

26) Upham, Law and Social Change in Japan, New York, 1988.

27) Mardjono, Op. Cit., hal. 55.

28) C.H. Mc Caghy, Deviant Behaviour. Crime, Conflict and Interest Group, New York: Mac Millan, 1976, hal. 216.
29) Steven Box, Power, Crime and Mystification, 1983, hal. 64.

30) Muladi dan Dwija P., Op. Cit., hal. 177.

31) Ulhrich Sieber, Criminal Abuse of Economic Power by Transnational Enterproses, hal. 25.

32) Heuvel, Op. Cit., hal. 6.

33) Mardjono Reksodiputro, Op. Cit., hal. 5.

34) Heuvel, Op. Cit., hal. 7.

35) J.E. Sahetapy, Kejahatan Korporasi Ditinjau dari Sudut Kriminologis, makalah pada seminar nasional Kejahatan Korporasi, FH UNDIP, 23-24 November 1989, hal. 20.

36) Susanto, Op. Cit., hal. 22.

37) Barda Nawawi Arif, Perbandingan Hukum Pidana, Jakarta: Rajawali, 1990, hal. 38.

\section{Daftar Pustaka}

Ali, Chidir, Badan Hukum, Bandung: Alumni, 1987.

Arief, Barda Nawawi, Perbandingan Hukum Pidana, Jakarta: Rajawali, 1990.

Box, Stephen, Power, Crime, adn Mystification, 1983.

Kuin, Pieter (penyunt.), Perusahaan Trans Nasional, Jakarta: Yayasan Obor dan Gramedia, 1987.

Mc. Caghy, C.H. Deviant Behaviour: Crime, Conflict and Interest Group, New York: Mac Millan, 1987.

Muladi dan Dwija P., Pertanggungjawaban Korporasi dalam Hukum Pidana, Bandung: STHB, 1991.

Rahardjo, Satjipto, Ilmu Hukum, Bandung: Alumni, 1987.

Sahetapy, J.E., Kejahatan Korporasi, Bandung: Eresco, 1994.

Sheley, Joseph F., Exploring Crime, 1987.

Wither Jr, William B. dan Keit Davis, Human Resources and Personnel Managament, New York: McGraw-Gill INC., 1993.

Kumpulan makalah seminar Kejahatan Kor-porasi, FH UNDIP, 1989 